\title{
Effects of Sensorimotor Training Volume on Recovery of Knee Joint Stability in Patients following Anterior Cruciate Ligament Reconstruction
}

\author{
Jae-Kwang Shim ${ }^{1}$, Ho-Suk Choi ${ }^{2}$ \\ 'Department of Physical Therapy, Graduate School of Daejeon University, Deajeon Wellness Hospital, Daejeon; ${ }^{2}$ Department of Physical Therapy, \\ Graduate School of Daejeon University, Daejeon, Korea
}

Purpose: The purpose of this study is to examine the effects of sensorimotor training on knee joint stability after anterior cruciate ligament reconstruction.

Methods: The subjects were sixteen 16 adults who received anterior cruciate reconstruction by arthroscopy, and underwent sensorimotor training for which was to have them maintenanceain of a standing position with a step Balance ball on the affected side over 30 degrees knee flexion with 100\% weight bearing for 15-20 seconds. Before the genuine experiment commenced, the Lysholm scale was had been used to assess functional disorders on the affected knee joint. KT-2000 Arthrometer measurement equipment was used to measure anterior displacement of tibia against to femur before and after the sensorimotor training.

Results: There was significant relaxation on the affected side in tibia anterior displacement of the affected and sound sides on in supine position before the sensorimotor training. There was little significant difference in tibia anterior displacement of the affected knee joints on in the supine position before and after the sensorimotor training. The results also showed that there was a reduction in the difference of tibia anterior displacement of the affected knee joints on in the standing position. These results suggest that the effects of sensorimotor training on knee joint stability after anterior cruciate ligament reconstruction is to induce the change of tibia anterior displacement against femur and the variation of muscles activation.

Conclusion: The sensorimotor training may contribute to the improvement of joint functional stability in people who are in post-operation state and with orthopedic musculoskelectal injuries.

Keywords: Anterior cruciate ligament reconstruction, Sensorimotor training, Arthrometer

\section{서 론}

최근 산업재해 및 교통사고, 여가활동에서 슬관절의 외상과 질병의 이환율이 증가하고 있다. 슬관절 손상 중 상당한 부분을 차지하는 인 대손상에 있어서 특히 전방십자인대의 중요성에 대한 관심이 고조되 고 있다. 슬관절의 안전성은 인대에 의존하기 때문에 슬관절의 각 인 대를 검사하는 것은 필수적이다. 관절의 동적 안정성은 수동적(인대) 그리고 능동적(근육) 요소에 의한 조절과 감각-운동의 협력 작용으 로 이루어지게 된다. 관절에서의 인대는 움직임을 제한하는 수동적 구조로서 안정성에 중요한 역할을 할뿐만 아니라 관절의 위치감각과 근육의 반사적 안정성을 조절하는 감각적 되먹임을 제공하여 일차적
인 기능적 안정성을 제공한다.1

전방십자인대 손상으로 인해 고유수용성 감각(proprioception), 기 능 수행 능력 그리고 대퇴사두근의 근력이 손상 측 슬관절에서 유의 하게 감소하였고 감소된 고유수용성감각은 그들의 기능적 능력 또한 감소시켰다고 보고하였으며, ${ }^{2}$ 보행 시 경골이 대퇴골에 대해 과도하 게 전방으로 이동하는 것을 보상하기 위해 슬괵근의 활동이 증가하 고 대퇴사두근의 활성은 억제된다고 보고하였다. ${ }^{3}$ 이러한 전방십자 인대 손상에 있어 기능적 안정성을 회복시키기 위하여 자가건 이식 (autograft) 혹은 동종건 이식(allograft)을 이용한 관절 내 전방십자인 대 재건술이 사용되고 있다. 그러나 재건술 후 관절의 움직임을 조절 하기 위한 고유수용성 감각의 결여와 변화를 초래하여 현저한 불안 
정성을 일으킬 수 있고, 이러한 불안정성은 재손상이나 관절연골과 다른 연부조직에 부하를 증가시켜 퇴행성 변화를 유발할 수 있다. 그 러므로 슬관절 전방십자인대 재건술 후 관절의 불안정성을 회복하 기 위한 적절한 중재의 필요로 수술 후 재활로써 운동치료의 중요성 이 대두되고 있다.'

운동을 치료적으로 사용하는 것은 물리치료의 중요한 부분이며, 치료 프로그램에는 능동 운동이 포함되어야 한다. 치료과정 중 운동 치료는 가능한 한 일찍 시작되어야 하며 재활 기간 중 운동 프로그램 지속적으로 시행이 필요하다. 감각-운동 훈련의 목적은 개선된 움직 임 및 패턴과 협응 활동(coordination), 증가된 근력, 지구력 그리고 민 첩성 등은 재발과 부상을 방지하는 것에 도움이 된다. 슬관절 재활 에 대한 적절한 운동 도구나 프로그램에 대한 연구를 계속하고 있으 며, ${ }^{5}$ 운동의 형태와 강도는 손상된 인대나 재활(rehabilitation)의 단계 에서 섬세하게 조절되어야 한다고 하였다. ${ }^{6}$

전방십자인대 재건술 후 재활에 대한 여러 연구에서 다양한 운동 방법이 연구되어 왔으며, 그에 대한 평가의 대부분 임상적 평가가 사 용되었다. 1,727 감각-운동 훈련을 통해서 슬관절의 안정성을 직접적이 고도 객관적으로 측정을 한 연구는 미미한 실정이다. 따라서 본 연구 는 목적은 전방십자인대 손상 환자의 재건술 후 감각-운동 훈련(sensorimotor training)을 객관적으로 평가하여 보다 환자들에게 기능적 인 도움을 주고, 감각-운동 훈련이 무릎의 안정에 어떠한 효과를 주 는지 관절계측기(arthrometer)를 이용하여 규명하고자 하였다.

본 연구의 가설은 다음과 같다.

첫째, 감각-운동 훈련 전후에 체중을 부하한 상태에서 관절계측기 측정은 차이가 있을 것이다.

둘째, 체중을 $100 \%$ 부하한 상태에서의 하지 근육들이 기능적으로 수축한 상태에서는 관절계측기 측정 시 감각-운동 훈련 전과 후에 대 퇴골에 대한 경골의 전방 끌림의 차이가 있을 것이다.

\section{연구방법}

\section{1. 연구대상 및 연구기간}

연구대상은 슬관절 손상으로 관절내시경(arthroscopy)에 의해 전방 십자인대 재건술을 시행하고, 재건술 후 최소 3 개월 이상 재활 운동 (재건술 1-3주: 홈 프로그램, 4-6주: 근육간 협응력(Intermuscular coordination) 개선, 7-9주: 국소적 근-지구력 개선, 10-12주: 근력의 증강)을 하였으며, 환자들 중 실험 내용을 이해하고 참여에 동의한 환자 19-50 세 사이의 성인 22 명(남자 14 명, 여자 8 명)을 대상으로 하였다.

본 연구에서 동종건 이식으로는 아킬레스 건이 15예, 자가건 이식 은 슬개건 4예와 반건양 건이 3 예 있었다. 동반 손상은 인대가 12 예로 제일 많았고, 내측 반월상 연골이 7예로 외측 반월상 연골 5예이며,
관절 연골의 병변과 골절이 각각 4 예 있었다. 무릎 이외의 근골격계에 병리학적 병력이 있는 환자는 제외하였다.

\section{2. 측정도구 및 실험방법}

\section{1) 측정도구 및 방법 \\ (1) 슬관절 불안정성}

본 연구에서는 본격적인 실험에 앞서 피험자들의 전방십자인대 재건 술 후 그 동안의 재활에 대한 정도를 알아보기 위하여, 그 중 다른 척 도보다 임상적으로 슬관절의 활동도와 불안정성에 대한 기능적 손 상을 평가하기에 적합한 Lysholm 척도를 사용하였다. 이것은 정상적 인 보행이 가능한지(5점), 체중부하의 정도(5점), 계단 오르기(10점), 쪼그려 앉기(5점), 걷기·달리기·점프와 같은 활동 시 불안정성(30점) 이나 통증(30점), 부종(10점)의 정도, 그리고 대퇴부 근위축(5점)의 정 도를 평가한다. 총점을 100점으로 하여 100-91: 우수, 90-82: 양호, 8162: 보통, 61-0: 불량으로 해석되며, 본 연구에서는 우수가 7예(31.82\%), 양호가 6예(27.27\%), 보통이 9예(40.91\%)였고, 평균 점수는 83.18점으로 양호(Good)한 결과를 보였다(Table 1).

\section{(2) 관절계측기}

슬관절의 불안정성을 평가할 때 느낌에 의해 주관적으로 행해지는 경우가 많다. 이런 주관적인 평가를 지양하고 슬관절의 불안정성을 객관적으로 측정하기 위해 만들어진 것이 관절계측기 (KT-2000, MEDmetric Corp, USA.)이다. KT-2000 관절계측기는 슬관절의 전후방 전위를 측정하기 위한 기계로 경골에 전방 또는 후방으로 힘을 가하 면서 슬개골과 경골 근위부에 놓인 두 개의 보조 패드 사이의 전위 (displacement)를 mm로 표시한다. 슬관절의 전방십자인대 손상에서 KT-2000 관절계측기는 일반적으로 신뢰할만한 기구라고 보고하고 있다. ${ }^{89}$

임상에서 대부분 관절계측기 측정은 환자가 바로 누운 자세(supine position)에서 이루어지는데, 본 연구에서는 슬관절이 기능적으로 쓰 일 때와 그렇지 않을 때를 비교하고자 바로 누운 자세와 선 자세

Table 1. General characteristics of subjects

\begin{tabular}{lc}
\hline Characteristics & $\mathrm{N}=22$ \\
\hline Gender & \\
(Male/Female) & $14 / 8$ \\
Age (year) & $34.0 \pm 2.4^{\mathrm{a}}$ \\
Weight $(\mathrm{kg})$ & $67.7 \pm 8.7$ \\
Height $(\mathrm{cm})$ & $167.2 \pm 5.5$ \\
BMl & $24.0 \pm 2.4$ \\
Lysholm scoring scale & $13.8 \pm 3.9$ \\
\hline
\end{tabular}

aValues are mean $\pm S D$.

BMl: Body mass index. 
(standing position)에서 환측 무릎에 체중을 $100 \%$ 부하 하고 무릎 $30^{\circ}$ 굴곡(flexion) 상태에서 측정을 하였다..$^{10}$ 기본적으로 바로 누운 자세 에서 관절계측기 측정을 보면 대퇴부지지대(thigh support)를 양측 대 퇴부 밑에 슬개골 상단위치와 일치하게 놓고, 족부지지대(foot support)는 양측 슬관절이 $30^{\circ}$ 굴곡위 및 $15^{\circ}$ 외회전위 상태에 대칭적으로 놓이게 족관절 외과면 직하부에 위치한다. 양측 슬관절을 표시한 후 관절계측기의 관절선(joint line) 화살표가 표시한 슬관절면과 일치하 게 경골부 위에 올려놓고 원위부 벨크로 스트렙(velcro strap)은 느슨하 게, 근위부 벨크로 스트렙은 단단히 환자의 하퇴부에 고정한다. 한 손 으로 하퇴부를 잡고 관절계측기의 정확한 위치를 재조정 한 후, 슬개 골 센서 패드(patellar sensor pad)에 압력을 가해서 슬개골이 내·외측 으로 이동하지 않도록 고정한다. 슬개골 센서 패드의 높이 조절나사 를 풀고 측정계기 바늘이 12 시 위치에 오도록 조정한 후 조절나사를 다시 조인다. 측정계기 바늘의 전방이동이 더 이상 증가되지 않을 때 까지 슬개골 센서 패드에 압력을 가한 후(압력 손잡이를 밀거나, 또는 당긴 후 압력을 제거하면 계기의 바늘이 원래의 위치에 되돌아오면 슬관절 주위의 근육이 충분히 이완 되었다고 판단됨) 다이얼(dial)을 돌려 눈금을 영점에 조정하고 슬개골 센서 패드에 지속적인 압력을 가하면서 수동적 전방전위검사를 시행한다. 손잡이 선상에 일치하게 부드럽고 지속적으로 전방으로 힘을 가하여 세 가지 음이 발생하도 록 하여 각각 $15 \mathrm{lb}, 20 \mathrm{lb}$ 와 $30 \mathrm{lb}$ 때의 음이 들리는 순간 측정계기 바늘 의 눈금을 읽어 경골의 전방전위를 기록한다. 마지막으로 도수최대전 방전위검사(manual maximum drawer test)를 시행하는데 한손으로 슬 개골 센서 패드에 지속적인 압력을 유지한 채 다른 한손으로 근위부 벨크로 스트렙이 있는 하퇴부를 잡고 최대한의 전방 전위력을 가한 후 측정계기 바늘의 눈금을 읽어 최대전방전위를 기록한다.11

\section{2) 실험방법}

감각-운동 훈련 및 KT-2000 관절계측기 측정은 환측 무릎 $30^{\circ}$ 굴곡 각도에서 이루어졌다. 피험자들은 먼저 바로 누운 자세에서 KT-2000 관절계측기로 환측 무릎의 전방전위를 측정하고, 선 자세에서 다시 환측 무릎의 전방전위를 측정하였다.

본 연구에서는 감각-운동 훈련 중에서 집중력, 하지 근력, 그리고

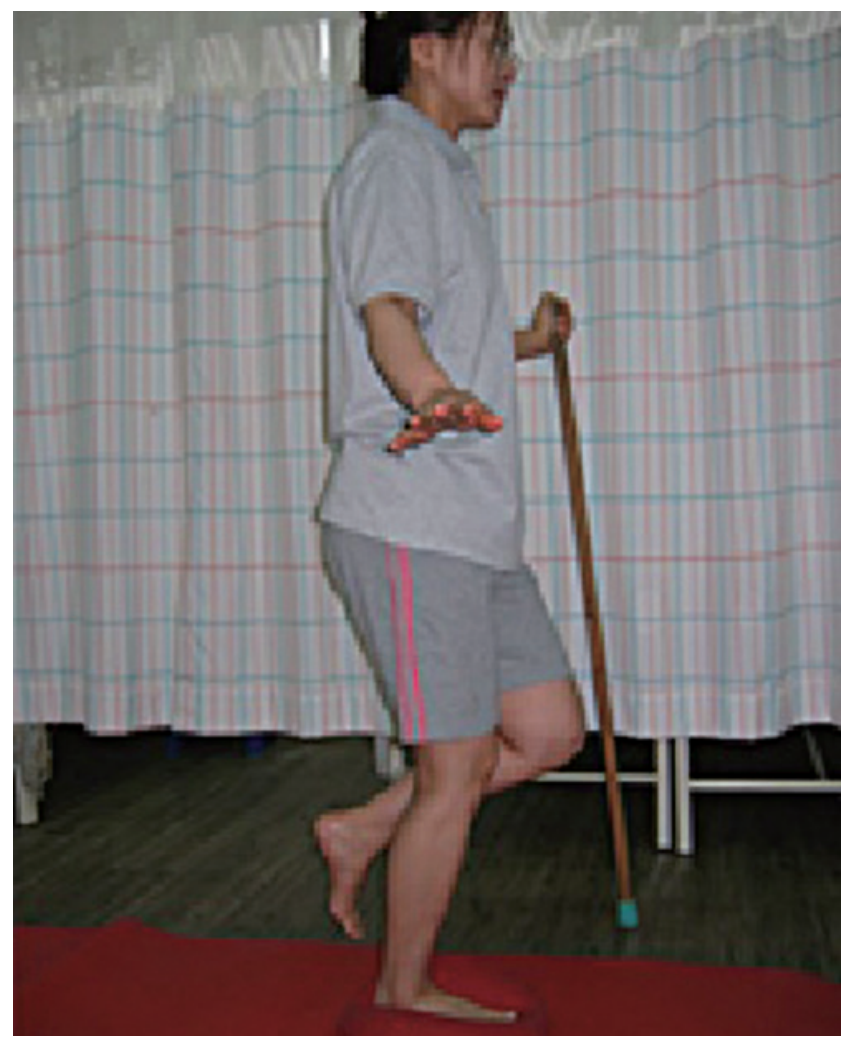

Figure 1. Sensorimotor training during the knee in $30^{\circ}$ of flexion with affected side load equivalent to $100 \%$ of body weight.

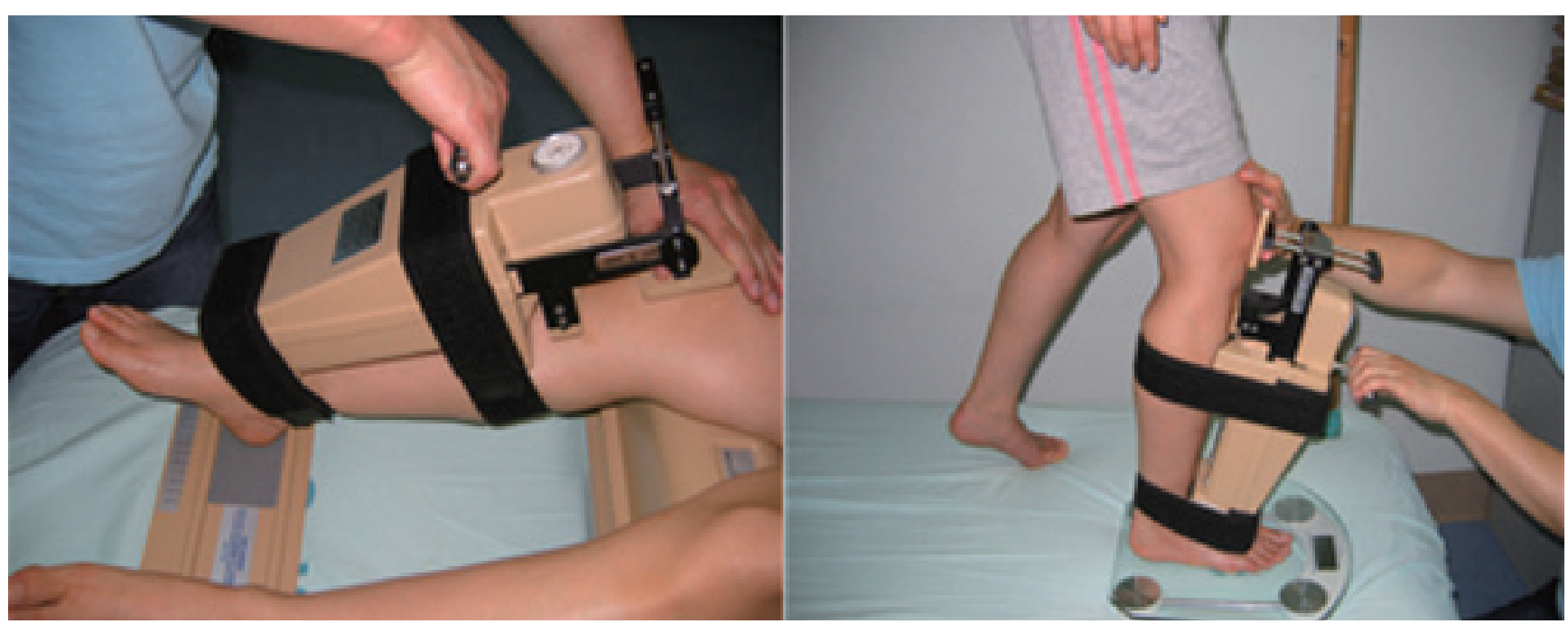

Figure 2. Arthrometer used to measure anterior tibial displacement during supine position and standing position. 
무릎의 안정성을 요하는 Balance ball (DYNAIR, TOGU, Germany)을 밟고 하는 운동을 선택하였다. Balance ball내의 공기의 양을 정량화 하기 위하여 공기를 주입한 Balance ball의 무게를 항상 $0.9 \mathrm{~kg}$ 으로 유 지하였다. 몇 번의 준비운동을 거쳐 충분히 휴식시간을 가진 후, 환 측으로 Balance ball을 밟고 100\% 체중을 부하한 상태에서 15-20초 유 지할 수 있는 시간을 가졌으며 3 회씩 훈련을 하고 사이사이에 휴식시 간은 3 분을 가졌다(Figure 1).

감각-운동 훈련 후 3 분 휴식을 하고, 선 자세에서 KT-2000 관절계 측기로 경골의 전방전위를 기록하였다. 마지막으로 바로 누운 자세에 서 환측 무릎의 경골 전방전위를 측정하였다(Figure 2).

\section{3) 자료처리 및 분석}

통계학적 분석은 SPSS 18.0 for Windows를 사용하였으며, KT-2000 관 절계측기로 감각-운동 훈련 시행 전과 후에 환측 무릎의 전방전위를 측정하였고, 결과값은 Kolmogorov-Smirnov 정규성 검정을 시행하였 다. 측정 결과 값이 정규성을 만족하지 못하여 비모수적 검정법인 윌 콕슨 부호-순위 검증(Wilcoxon signed rank test)을 이용하였다. 통계학 적인 유의성을 검정하기 위한 유의수준은 $\mathrm{p}<0.05$ 로 하였다.

\section{결 과}

연구에 참가한 대상자 중 남자가 14 명, 여자가 8 명이었다. 전체 대상자 의 평균 연령은 34.0 세, 평균 체중은 $67.7 \mathrm{~kg}$, 평균 신장은 $167.2 \mathrm{~cm}$, 평 균 신체질량지수(body mass index, $\mathrm{BMI})$ 는 $24.0\left(\mathrm{~kg} / \mathrm{m}^{2}\right)$ 으로 측정되었 다(Table 1).

바로 누운 자세에서 관절계측기로 측정한 환측의 경골 전방전위 는 감각-운동 훈련 전후에 환측의 에서가 유의한 차이를 나타나지 않 았지만( $\mathrm{p}>0.05)$, 수동 최대 전위에서는 $0.68 \pm 1.13 \mathrm{~mm}$ 으로 유의한 차 이가 나타났다 $(\mathrm{p}<0.05)$. 선 자세에서는 감각-운동 훈련 전후에 환측 의 경골 전방 전위차이는 $15 \mathrm{lb}$ 에서 $0.59 \pm 0.50 \mathrm{~mm}, 20 \mathrm{lb}$ 는 $0.77 \pm 0.75$ $\mathrm{mm}, 30 \mathrm{lb}$ 는 $1.18 \pm 1.05 \mathrm{~mm}$ 로 유의한 차이가 나타났으며, 수동 최대 전위 차이도 $1.91 \pm 1.63 \mathrm{~mm}$ 로 신경근 운동 전후에 유의한 차이를 나 타났다 $(\mathrm{p}<0.05)$ (Table 2).

\section{고 찰}

슬관절의 안정성을 유지하는데 슬관절을 지지해주는 인대와 관절 주위 근육이 중요한 역할을 한다. 이중 전방십자인대는 1 차적으로 경 골의 전방전위를 주로 억제하고, 2 차적으로는 완전신전에서 내· 외반 과 회전을 억제한다. ${ }^{12}$ 또한 무릎의 신전과 과신전을 견제하며, 무릎 의 정상적인 회전과 미끄러짐을 조절하여 도와준다. 전·내측 다발들
Table 2. Comparison of tibial anterior displacement between pre and post training using KT-2000 arthrometer in supine and standing position

\begin{tabular}{clcccc}
\hline & & Pre-training & Post-training & Pre-Post & Z \\
\hline Supine & $(15 \mathrm{lb})$ & $4.23 \pm 1.51$ & $4.05 \pm 1.17$ & $0.18 \pm 0.66$ & -1.265 \\
A.T.D. & $(20 \mathrm{lb})$ & $6.41 \pm 1.97$ & $6.18 \pm 1.56$ & $0.23 \pm 0.97$ & -1.278 \\
& $(30 \mathrm{lb})$ & $9.09 \pm 2.27$ & $8.86 \pm 2.10$ & $0.23 \pm 0.92$ & -1.115 \\
Standing & $(15 \mathrm{lb})$ & $1.82 \pm 0.59$ & $1.23 \pm 0.43$ & $0.59 \pm 0.50$ & $-3.606^{*}$ \\
A.T.D. & $(20 \mathrm{lb})$ & $3.01 \pm 0.82$ & $2.23 \pm 0.42$ & $0.77 \pm 0.75$ & $-3.314^{*}$ \\
& $(30 \mathrm{lb})$ & $4.32 \pm 1.13$ & $3.14 \pm .64$ & $1.18 \pm 1.05$ & $-3.624^{*}$ \\
Supine & M.M.D. & $14.09 \pm 2.33$ & $13.41 \pm 2.17$ & $0.68 \pm 1.13$ & $-2.675^{*}$ \\
Standing & M.M.D. & $7.23 \pm 1.97$ & $5.32 \pm 1.04$ & $1.91 \pm 1.63$ & $-3.762^{*}$
\end{tabular}

Values are mean $\pm S D . m m(N=22),{ }^{*} p<0.5$.

A.T.D: Anterior tibial displacement, M.M.D: Manual maximum displacement, Pre-Post: Pre-training-post-training.

은 굴곡과 신전시 양쪽 모두에서 팽창하는 반면 후·외측다발들은 단 지 신전에서 팽창하며, 전체적으로 전방십자인대는 $30^{\circ}$ 와 $60^{\circ}$ 굴곡 사이에서 최소의 스트레스를 받는다. ${ }^{13}$ 만약 1 차적인 억제가 손상 받 는다면 병적인 운동이 발생한다. 그러나 2차적인 억제가 손상을 받았 지만 1 차적인 억제가 손상 받지 않았다면, 그 방향의 병적 운동은 일 어나지 않는다. 결국 1 차와 2 차적인 억제 모두가 손상된다면 병적인 움직임이 더 커지게 된다. ${ }^{14}$

전방십자인대는 주행방향이 사선이기 때문에 극단적인 움직임에 저항하여 넓은 범위의 안정성을 제공하지만 이러한 특성 때문에 쉽 게 손상을 입게 된다. 특히 발이 지면에 고정되어 있는 동안 과도하게 슬관절이 신전되는 기전 동안 대퇴사두근의 의해 생성되는 큰 힘은 손상의 심각성을 더욱 증가시킬 수 있다. ${ }^{15}$ 대퇴사두근은 매우 중요한 슬관절의 동적 안정근으로서의 역할을 수행하고, 슬괵근은 전방십 자인대의 역동적 주동근으로 작용하여 슬관절의 전방 아탈구의 예 방에 가장 중요한 역할을 수행한다. 따라서 이들 두 근육의 위축이 심 할수록 더 심한 증상을 호소하고, 기능적 장애가 심해질 것으로 추정 할 수 있다. 이렇듯 전방십자인대는 슬관절의 전방 안정성에 중요한 구조물로 손상을 받아 파열이 있을 경우에는 통증을 동반한 슬관절 의 불안정성이 나타난다. 선행연구에서 32 명의 전방십자인대 파열 환 자를 대상으로 한 연구에서 손상 측의 기능 수행 능력이 감소하였다 고 보고하였고, ${ }^{2}$ 전방십자인대 손상 시 대퇴사두근과 슬괵근의 근력 이 유의하게 감소하였다고 보고하였다. ${ }^{16}$

전방십자인대 재건술의 적응증은 일반적으로 일상 활동 중 나타 나는 불안정성, 생활 방식을 바꿀 수 없는 환자에게서 슬관절의 기능 적 손상을 보일 때, 보존적 치료로 실패했을 경우, 수술 후 장기적인 재활이 가능한 경우 등으로 알려져 있으며, ${ }^{17}$ 또한 젊고 활동적인 사 람들의 일상 생활에서 허약감 등의 기능 제한이 있을 경우나 육체적 인 직장 생활이 필요한 사람들에게서 주로 시행 되어진다. ${ }^{18}$ 
관절의 고유수용성 감각은 일반적으로 신체부위에 대한 상대적 위치와 움직임을 결정하는 관절의 위치 감각과 운동 감각과 관련이 있다. 고유수용성 감각에 기여하는 말초의 기계적 수용기(mechanoreceptor)들은 관절, 근육, 결합조직과 인대조직에서 풍부하게 분포되 어지고 신경근 조절, 근육 조절 그리고 관절의 안정성을 확보하고 유 지하는데 중요한 되먹임의 요소로서 관절의 안정화에 중요한 역할을 한다. ${ }^{19}$ 그리고 예전에는 운동 감각과 관절의 위치 감각은 관절낭과 인대에 있는 이러한 기계적 수용기에서 거의 단독적으로 참여한다고 생각하였으나, 최근에는 근방추와 관절과 결합하고 있는 건의 구심 성 섬유에 의한 감각적 역할의 중요성을 강조하고 있다. ${ }^{20}$ 전방십자인 대 재건술 후 9 개월 이상부터 고유수용성 감각이 점진적으로 증진되 고 수술 후 관절의 안정성 증진은 고유수용성 감각의 회복을 촉진한 다고 보고되었다.16

본 연구는 슬관절 손상으로 관절내시경에 의해 전방십자인대 재 건술을 받은 환자를 대상으로 하였는데 피험자들은 최대근력, 관절 각도, 협응 활동 등을 측정한 후 개인별 질환과 상태에 맞는 운동 프 로그램을 만들어서 최소 3 개월 이상 재활 운동을 받고, 슬관절의 안 정성을 증진시켰다. 전방십자인대 재건술 후 표준화된 재활 프로그 램을 적용한 후 3 개월 내지 6 개월 후에 측정한 고유수용성 감각이 손 상측과 비손상측 모두에서 유의하게 증가하였다고 보고하였다. ${ }^{21}$

다양한 재활 운동 프로그램 중에서 본 연구에서는 감각-운동 훈련 을 선택하였는데 그 중에서도 고도의 집중력, 하지 근력, 그리고 무릎 의 안정성을 요하는 Balance ball을 밟고 체중을 $100 \%$ 부하한 상태에 서 무릎 굴곡 $30^{\circ}$ 를 유지하는 운동을 선택하였다. 정적인 지면에 균형 판과 에어쿠션 위에서 하는 운동은 더 많은 기계적 수용기를 자극하 고 근육의 동원을 증가시켜 대퇴사두근과 슬괵근을 근력을 효과적 으로 증진시키고 동적 관절 안정성을 조절하기 위한 구심성 정보와 중추적 기전을 자극함으로써 무의식적인 운동반응이 일어나도록 한 다. 감각-운동 훈련 전후의 슬관절의 불안정성을 객관적으로 측정하 기 위하여 관절계측기를 사용하였는데, 이는 기계식 압박에 의해 검 사하고자 하는 관절주위에 일정한 힘을 가함으로서 그 부위의 인대 이완 정도를 정량화하여 표현할 수 있고, 검사자의 순간인 힘에 의해 결과를 나타내는 도수 스트레스 검사에 비해 재현성이 높은 것으로 알려져 있다. 선행연구들에서는 정상적인 슬관절부에 각기 다른 날 매회 새로운 장착을 하여 반복 검사한 결과 유의한 차이가 없음이 보 고되었고, ${ }^{9}$ 각기 다른 종류의 상품화된 관절계측기를 이용하여 동일 인에 측정한 결과, 각 기구간의 차이가 없었음을 보고하였다.922

많은 연구가들에 의하면 전방십자인대 파열에 의한 전방전위는 슬관절을 $15-45^{\circ}$ 굴곡위에서 가장 잘 관찰될 수 있다고 한다. 슬관절 의 굴곡정도에 따라 전후방전위차에 변동이 생기므로, 양측 슬관절 간의 전위차 비교를 위해서는 양측 슬관절을 같은 굴곡위 상태로 하
는 것이 중요하다. ${ }^{23}$ 본 연구에서는 대퇴부지지대를 이용하여 양측슬 관절이 $30^{\circ}$ 굴곡위에 놓이도록 하였다. 정상 슬관절과 전방십자인대 가 파열된 슬관절 모두에서 외측 경골과가 내측 경골과보다 전후방 전위차가 더욱 크며 슬관절의 전후방 부하시 전위 및 회전이 동시에 발생하여 경골의 전방전위시는 내회전이, 경골의 후방전위 시는 외회 전이 병행된다. ${ }^{24}$ 따라서 슬관절의 회전 제한시 경골의 전방전위는 약 $30 \%$ 정도까지 감소하게 되므로, ${ }^{25}$ 본 연구에서는 족부지지대를 이용 하여 양측 슬관절이 $15^{\circ}$ 외회전위에 대칭적으로 놓이게 하여 부하검 사시 내회전을 제한하지 않았다. 근육이 충분히 이완되지 않은 상태 에서 검사하면 정상치의 $25-50 \%$ 의 감소를 가져온다고 보고하였으며 환자를 편안한 위치에서 검사하여야 하고 검사자는 환자가 충분히 근 이완된 상태인지를 평가하고 실시하여야 근 수축에 의한 오차를 최소화 할 수 있다고 하였다. ${ }^{26}$ 또한 관절계측기는 슬개골 센서 패드 와 경골 결절 센서 패드(tibial tubercle sensor pad)사이의 상대적 전위 를 측정하는 기계로, 경골과 대퇴골 사이의 상대적 전위를 정확하게 측정하기 위해서는 검사하는 동안에 일정한 압력으로 슬개골 센서 패드를 슬개골에 단단히 고정하고, 즉 슬개골을 대퇴골 활차에 단단 히 고정하여 측정함으로서 오차를 줄일 수 있다.

전방십자인대 손상은 관절의 고유수용성 감각의 결여, 대퇴사두 근의 근력약화 그리고 관절의 불안정성을 초래하여 능동적인 신전 마지막 범위의 상실, 불충분한 보행, 관절 연골의 마모를 유발할수 있 다. 그러므로 십자인대 손상 후 통증의 감소뿐만 아니라 기능적 활동 에 필요한 고유수용성 감각과 근력의 회복이 동반되어져야 한다. 감 각-운동 훈련 전후에 바로 누운 자세에서 환측간의 경골 전방전위차 는 유의한차이를 나타내지 못했다. 하지만 선 자세에서 환측간의 경 골 전방전위는 감각-운동 훈련 전후에 전위차를 보이면서 유의한 차 이를 나타냈다. 이것은 감각-운동 훈련이 인대의 변화에는 효과가 적 었지만, 근력과 고유수용성 감각에 긍정적 요소로 작용 된 것으로 사 료된다. 따라서 전방십자인대 재건술 후 회복하기 위한 운동치료 중 운동학적 측면에서 전방십자인대의 생체역학을 고려하여 이식된 인 대에 좌상을 최소화하고 치유를 촉진할 수 있는 운동이 선택되어져 야 한다. ${ }^{27}$ 체중부하를 이용한 감각-운동 훈련은 근육의 협응, 관절의 적합성을 증가시켜 관절의 동적 안정성 제공하고, 기능적 위치에서 의 자세유지 훈련은 점진적인 기계적 압력을 통해 연부조직의 치유 촉진으로 더 많은 고유수용성 감각을 제공할 수 있다. ${ }^{28}$ 그러므로 전 방십자인대 재건술 후 초기의 재활 후 관절의 전후 전단력을 최소화 하면서 고유수용성 감각, 슬관절 굴곡근과 신전근의 근력 그리고 기 능적 능력을 증가시키는 운동으로 감각-운동 훈련이 권장되어야 한 다고 생각한다.

본 연구는 연구대상을 한정하여 전체 전방십자인대 재건술을 시 행한 환자들에 대한 결과를 모두 알 수가 없다는 단점이 있고, 실험방 
법에서 감각-운동 훈련 방법 중 하나만 선택한 점과, KT-2000 관절계 측기 검사가 동일 검사자가 시행하여 이에 따른 오류가 있을 가능성 을 완전히 배제할 수는 없다. 이와 같은 제한점이 있지만 본 연구의 목 적이 전방십자인대 재건술 후의 단순한 슬관절의 안정성에 대한 결 과 보고라기보다는 주관적인 증상을 알고 슬관절의 기능적 안정성 을 객관적인 검사를 통해 알아보기 위한 것이므로 본 연구의 결과는 의미가 있다고 할 수 있겠다.

\section{REFERENCES}

1. Chinnavan E, Gopaladhas S, Saha A et al. Effectiveness of proprioceptive training in grade-ii acute anterior cruciate ligament injury in athletes. Indian Journal of Science and Technology. 2014;7(12):2041-5.

2. Katayama M, Higuchi H, Kimura M et al. Proprioception and performance after anterior cruciate ligament rupture. Int Orthop. 2004;28(5): $278-81$.

3. Wexler G, Hurwitz DE, Bush-Joseph CA et al. Functional gait adaptations in patients with anterior cruciate ligament deficiency over time. Clin Orthop Relat Res. 1998;348:166-75.

4. Pohl T, Brauner T, Wearing $S$ et al. Effects of sensorimotor training volume on recovery of sensorimotor function in patients following lower limb arthroplasty. BMC Musculoskelet Disord. 2015;16(1):195.

5. Risberg MA, Mørk M, Jenssen HK et al. Design and implementation of a neuromuscular training program following anterior cruciate ligament reconstruction. J Orthop Sports Phys Ther. 2001;31(11):620-31.

6. Beutler AI, Cooper LW, Kirkendall DT et al. Electromyographic analysis of single-leg, closed chain exercises: Implications for rehabilitation after anterior cruciate ligament reconstruction. Journal of athletic training. 2002;37(1):13.

7. Fitzgerald GK. Open versus closed kinetic chain exercise: Issues in rehabilitation after anterior cruciate ligament reconstructive surgery. Phys Ther. 1997;77(12):1747-54.

8. Myrer JW, Schulthies SS, Fellingham GW. Relative and absolute reliability of the kt-2000 arthrometer for uninjured knees testing at 67, 89, 134, and $178 \mathrm{n}$ and manual maximum forces. Am J Sports Med. 1996;24(1): 104-8.

9. Wroble RR, Van Ginkel LA, Grood ES et al. Repeatability of the kt-1000 arthrometer in a normal population. Am J Sports Med. 1990;18(4):3969.

10. Mellor R, Hodges PW. Motor unit synchronization of the vasti muscles in closed and open chain tasks. Arch Phys Med Rehabil. 2005;86(4):71621.

11. Küpper J, Loitz-Ramage B, Corr D et al. Measuring knee joint laxity: A review of applicable models and the need for new approaches to minimize variability. Clin Biomech. 2007;22(1):1-13.

12. Mir SM, Talebian S, Naseri N et al. Assessment of knee proprioception in the anterior cruciate ligament injury risk position in healthy subjects: A cross-sectional study. J Phys Ther Sci. 2014;26(10):1515.

13. Detenbeck LC. Function of the cruciate ligaments in knee stability. Am J Sports Med. 1974;2(4):217-21.

14. Irrgang J, Safran M, Fu F. The knee: Ligamentous and meniscal injuries. Athletic injuries and rehabilitation. 1996:623-92.

15. Neumann DA. Kinesiology of the musculoskeletal system: Foundations for rehabilitation. Elsevier Health Sciences, 2013: Pages.

16. Iwasa J, Ochi M, Adachi $\mathrm{N}$ et al. Proprioceptive improvement in knees with anterior cruciate ligament reconstruction. Clin Orthop Relat Res. 2000;381:168-76

17. Hewett TE, Di Stasi SL, Myer GD. Current concepts for injury prevention in athletes after anterior cruciate ligament reconstruction. Am J Sports Med. 2013;41(1):216-24.

18. Brewer BW, Cornelius AE, Van Raalte JL et al. Predictors of adherence to home rehabilitation exercises following anterior cruciate ligament reconstruction. Rehabilitation psychology. 2013;58(1):64.

19. Voight ML, Hardin JA, Blackburn TA et al. The effects of muscle fatigue on and the relationship of arm dominance to shoulder proprioception. J Orthop Sports Phys Ther. 1996;23(6):348-52.

20. Smith TO, Davies L, Hing CB. A systematic review to determine the reliability of knee joint position sense assessment measures. Knee. 2013; 20(3):162-9.

21. Reider B, Arcand MA, Diehl LH et al. Proprioception of the knee before and after anterior cruciate ligament reconstruction. Arthroscopy. 2003; 19(1):2-12.

22. Collette M, Courville J, Forton M et al. Objective evaluation of anterior knee laxity; comparison of the kt-1000 and gnrb ${ }^{\circledR}$ arthrometers. Knee Surg Sports Traumatol Arthrosc. 2012;20(11):2233-8.

23. Caplan N, Kader DF. Stiffness and laxity of the knee: The contributions of the supporting structures: A quantitative in vitro study. Classic papers in orthopaedics, Springer, 2014:137-9.

24. Struewer J, Frangen TM, Ishaque B et al. Knee function and prevalence of osteoarthritis after isolated anterior cruciate ligament reconstruction using bone-patellar tendon-bone graft: Long-term follow-up. Int Orthop. 2012;36(1):171-7.

25. Porter MD, Shadbolt B. "Anatomic" single-bundle anterior cruciate ligament reconstruction reduces both anterior translation and internal rotation during the pivot shift. Am J Sports Med. 2014;42(12):2948-54.

26. Kiapour AM, Wordeman SC, Paterno MV et al. Diagnostic value of knee arthrometry in the prediction of anterior cruciate ligament strain during landing. Am J Sports Med. 2013:0363546513509961.

27. Cho S-H, Bae C-H, Gak H-B. Effects of closed kinetic chain exercises on proprioception and functional scores of the knee after anterior cruciate ligament reconstruction. J Phys Ther Sci. 2013;25(10):1239.

28. Snyder-Mackler L. Scientific rationale and physiological basis for the use of closed kinetic chain exercise in the lower extremity. J Sport Rehabil. 1996;5:2-12. 